\title{
PERBEDAAN HASIL BELAJAR AKUNTANSI KEUANGAN \\ MENENGAH 1 ANTARA GAYA KOGNITIF "FIELD INDEPENDENT " DAN "FIELD DEPENDENT
}

\author{
Nunuk Suryanti \\ Universitas Islam Riau \\ nunuksuryanti@yahoo.com
}

\begin{abstract}
This research purpose to examine whether there is difference of intermediate accounting learning outcomes between "field independent" students and "field dependent" students . This study used survei approach. The population are from 288 accounting students with 167 samples. Instrument of student's cognitive style by GEFT. Student's academic achievement from accounting department's data. The results showed that there is differences on the students' intermediate accounting learning outcomes between "field independent" students and "field dependent" students.
\end{abstract}

Keywords: cognitive Style, field independent, field dependent.

\begin{abstract}
Abstrak: Penelitian ini merupakan penelitian survei, bertujuan untuk menguji apakah ada perbedaan hasil belajar Akuntansi Keuangan Menengah 1 (AKM 1) pada mahasiswa yang memiliki gaya kognitif field independent dan field dependent. Populasi dalam penelitian ini adalah mahasiswa semester empat jurusan akuntansi Universitas Negeri Malang yang telah menempuh AKM 1 terdiri dari 288 mahasiswa dengan mengambil sampel sebanyak 167 mahasiswa. Metode pengumpulan data menggunakan dokumentasi untuk data hasil belajar dan tes (GEFT) untuk mengukur gaya kognitif. Teknik analisis data dengan menggunakan independent sample $t$ test. Hasil penelitian menunjukkan bahwa ada perbedaan hasil belajar AKM 1 diantara mahasiswa yang memiliki dimensi gaya kognitif field independent dengan field dependent.
\end{abstract}

Kata kunci: gaya kognitif, field dependent, field independent.

Gaya kognitif merupakan jenis karakteristik individu yang berfungsi untuk menunjukkan secara keseluruhan aktivitas persepsi dan intelektual dengan konsistensi yang tinggi dan meresap pada setiap individu (Witkin, 1971). Menurut Allinson dan Hayes (1996), gaya kognitif adalah perbedaan pilihan perilaku kognitif, berfikir, dan ingatan yang akan mempengaruhi perilaku dan aktivitas individu baik secara langsung maupun tidak langsung. Dari definisi tersebut dapat disimpulkan bahwa gaya kognitif (cognitive style) merupakan gaya berfikir seseorang yang melibatkan kemampuan kognitif dalam kaitannya dengan bagaimana individu menerima, menyimpan, mengolah dan menyajikan informasi dimana gaya tersebut akan terus melekat dengan tingkat 
konsistensi yang tinggi yang akan mempengaruhi perilaku dan aktivitas individu baik secara langsung maupun tidak langsung.

Mengarah pada definisi di atas, gaya kognitif mempunya andil yang cukup besar dalam kinerja seseorang, termasuk dalam bidang prestasi mahasiswa dalam jurusan akuntansi sehingga perlu dikaji secara mendalam. Dimensi gaya kognitif terdiri dari Field Independent (FI) dan Field Dependent (FD) (Witkin (1971). Mahasiswa yang menempati area field-dependence beresiko terhadap pencapaian hasil belajar yang buruk, sedangkan mahasiswa yang berada pada dimensi field-independence cenderung lebih sukses dalam belajar (Tinajero dan Páramo, 1997). Hasil yang sama juga terjadi terhadap mahasiswa akuntansi di Brazil (Oliveira dan Souza, 2009) dalam (Tinajero, Lemos, Araújo, Ferraces, Páramo, 2012). Pengaruh gaya kognitif telah dianalisis baik untuk mengetahui pengaruhnya terhadap prestasi akademik untuk subjek tertentu maupun secara keseluruhan.

Penelitian selama 30 tahun yang telah dilakukan oleh Witkin (1977:149), menunjukkan bahwa pendekatan cognitive style dimensi FI dan FD bermanfaat jika diterapkan untuk permasalahan yang berhubungan dengan pendidikan. Berdasarkan kecukupan bukti yang berhasil dikumpulkan, dimensi FI dan FD memiliki dampak bagi dunia pendidikan yaitu mengenai bagaimana siswa belajar, bagaimana guru mengajar, bagaimana siswa dan guru berinteraksi, serta bagaimana siswa membuat keputusan dalam memilih pekerjaan. Untuk penelitian yang dilakukan oleh Davis (1991) menunjukkan bahwa ada sebuah pola yang konsisten bahwa siswa field independent tampil secara signifikan lebih baik daripada siswa dengan dimensi field dependent kurang lebih dalam seluruh area kurikulum.

Gaya kognitif sangat relevan untuk mengidentifikasi keterampilan problem solving yang memang diperlukan mahasiswa dalam menempuh mata kuliah AKM 1 karena kemampuan ini sangat dibutuhkan bagi pengguna lulusan (Jones dan Wright, 2012). Hicks, Bagg, Doyle, dan Young (2007) juga menunjukkan bahwa akuntan cenderung lebih analitis daripada intuitif. Bidang akuntansi, engineering and science cenderung masuk dalam dimensi field independent.

AKM 1 merupakan salah satu mata kuliah level atas pertama yang diambil mahasiswa dan merupakan dasar mata kuliah selanjutnya (Carrington, 2012; Eikner dan Montondon, 2001; Waples dan Darayseh, 2005). Hal ini menunjukkan bahwa 
keberhasilan mahasiswa dalam menempuh matakuliah ini sangat menentukan keberhasilan mahasiswa dalam menempuh mata kuliah level berikutnya. Oleh karena itu, AKM 1 menjadi "gateway" dari potensi seseorang dalam jurusan akuntansi dan bisa dijadikan prediktor yang baik dalam menentukan keberhasilan mahasiswa dalam jurusan akuntansi (Carrington, 2012; Campbell, Choo, Lindsay, Tan, 2010). Dengan demikian, pengetahuan atas gaya kognitif mahasiswa dapat digunakan sebagai prediksi prestasi akademik untuk subjek tertentu dalam hal ini akuntansi maupun secara keseluruhan.

Berdasarkan pemaparan di atas, dapat simpulkan bahwa mahasiswa yang memiliki kecenderungan gaya kognitif field independent akan memiliki hasil belajar lebih bagus dibandingkan dengan mahasiswa yang memiliki kecenderungan gaya kognitif field dependent sehingga diturunkan hipotesis sebagai berikut:

H1: Ada perbedaan hasil belajar AKM 1 mahasiswa yang memiliki gaya kognitif field independent dengan field dependent

\section{METODE}

Penelitian ini merupakan penelitian survei dimana tidak ada perlakuan khusus terhadap variabel yang teliti. Teknik analisis yang digunakan dalam penelitian ini adalah uji t dengan dua sampel/ independent sample t test. Penggunaan independent sample $t$ test untuk mengetahui apakah ada perbedaan hasil belajar Akuntansi Keuangan Menengah 1 pada mahasiswa dengan gaya kognitif field independent dan field dependent. Syarat penggunaan uji ini adalah uji normalitas. Uji normalitas dimaksudkan untuk mengetahui apakah residual yang diteliti berdistribusi normal atau tidak. Jika nilai residual berdistribusi normal, maka kurva berbentuk lonceng yang kedua sisinya melebar sampai tidak terhingga.

Populasi dalam penelitian ini terdiri dari mahasiswa semester empat Jurusan Akuntansi Universitas Negeri Malang yang baru saja menempuh Akuntansi Keuangan Menengah 1. Tabel 1 berikut ini adalah rincian populasi penelitian. 
Tabel 1. Populasi Penelitian

\begin{tabular}{|l|l|l|}
\hline Program Studi & OFF & Jumlah \\
\hline \multirow{4}{*}{ S1 Akuntansi } & EE & 43 \\
\cline { 2 - 3 } & C & 42 \\
\cline { 2 - 3 } & D & 46 \\
\cline { 2 - 3 } & FF & 44 \\
\hline \multirow{2}{*}{$\begin{array}{l}\text { S1 Pendidikan } \\
\text { Akuntansi }\end{array}$} & A & 43 \\
\hline D3 Akuntansi & BB & 43 \\
\hline Jumlah & G & 27 \\
\hline
\end{tabular}

Sumber: Jurusan Akuntansi UM

Teknik pengambilan sampel yang digunakan adalah simple random sampling. Sementara, penentuan jumlah sampel penelitian menggunakan rumus Slovin dan Taro Yamane sebagai berikut:

$$
n=\frac{N}{1+N d^{2}}
$$

Keterangan:

$$
\begin{array}{ll}
\mathrm{n} & =\text { besarnya sanpel } \\
\mathrm{N} & =\text { besarnya Populasi } \\
\mathrm{d} & =\text { kesalahan yang bisa ditolerir }(0,05)
\end{array}
$$

Berdasarkan rumus Slovin dan Taro Yamane di atas, diperoleh 167 sampel penelitian.

Pengukuran gaya kognitif (cognitive style) menggunakan instrumen tes gaya kognitif yang dikembangkan oleh Witkin (1971) yang diberi nama GEFT (Group Embedded Figures Test). GEFT merupakan tes dimana setiap individu diarahkan untuk mencari serangkaian bentuk sederhana yang berada dalam bentuk yang lebih kompleks dan lebih besar, didesain sedemikian rupa sehingga memasukkan atau menyembunyikan bentuk sederhana tersebut. Tes ini tediri dari 3 bagian, bagian pertama terdiri dari tujuh soal dimana hanya berfungsi sebagai latihan sehingga hasilnya tidak diperhitungkan. Bagian kedua dan ketiga terdiri dari 9 soal yang masing-masing diberi skor 1 untuk jawaban yang benar dan 0 untuk jawaban yang salah, sehingga skor maksimal tes sebesar 18 dan minimal 0.

Dalam menentukan kelompok mahasiswa yang tergolong dimensi field independent atau field dependent digunakan kategori yang dirumuskan oleh Gordon dan Wyant (1994) dimana skor 0 sampai 11 dikategorikan sebagai kelompok FD, dan skor 
12 sampai dengan 18 dikategorikan sebagai kelompok FI. Penggunaan instrumen GEFT dalam penelitian ini disebabkan tes ini dilengkapi latihan pada awalnya sehingga mahasiswa mengerjakan tes ini dengan jelas tanpa kesulitan, waktu yang diperlukan untuk mengerjakan tes ini cukup singkat sekitar 20 menit, tes ini mudah diadministrasikan, tidak memerlukan keterampilan dan keahlian khusus, tes ini reliabel dan valid karena sudah mengalami sejumlah pengujian (Tegeh, 2009). Hasil belajar AKM 1 menggunakan instrumen dokumentasi. Dokumen skor akhir hasil belajar AKM 1 diperoleh dari pihak Jurusan Akuntansi Fakultas Ekonomi Universitas Negeri Malang.

\section{HASIL DAN PEMBAHASAN}

Berdasarkan hasil penelitian, data sampel telah terdistribusi normal. Hasil pengolahan data gaya kognitif dan hasil belajar AKM 1 mahasiswa seperti dalam tabel 2 berikut ini.

Tabel 2: Gaya Kognitif dan Hasil Belajar AKM I Mahasiswa Group Statistics

\begin{tabular}{|ll|l|l|l|l|}
\hline & Gaya_Kognitif & $\mathrm{N}$ & Mean & $\begin{array}{l}\text { Std. } \\
\text { Deviation }\end{array}$ & $\begin{array}{l}\text { Std. Error } \\
\text { Mean }\end{array}$ \\
\hline Nilai & 1 & 62 & 71.2274 & 12.04336 & 1.52951 \\
& 2 & 105 & 75.4405 & 10.64249 & 1.03860 \\
\hline
\end{tabular}

Berdasarkan data tersebut, mahasiswa yang tergolong ke dalam gaya kognitif field dependent diberikan simbol (1) sebanyak 62 orang dengan nilai rata-rata hasil belajar AKM 1 adalah 71,23. Mahasiswa yang tegolong field independent diberikan simbol (2) sebanyak 105 orang dengan nilai rata-rata hasil belajar AKM 1 adalah 75,44. Dengan demikian terjadi perbedaan hasil belajar AKM I dilihat dari nilai rata-rata, dimana mahasiswa dengan gaya kognitif field independent lebih tinggi daripada field dependent. Dilihat dari sisi jumlah, mahasiswa jurusan akuntansi UM cenderung lebih memiliki gaya kognitif field independent.

Hasil pengujian hipotesis bisa dilihat dari hasil uji independent sample t test dalam tabel 3 berikut ini: 
Tabel 3: hasil uji Independent sample t test

\begin{tabular}{|ll|l|l|}
\hline \multirow{2}{*}{} & \multicolumn{2}{|l|}{ Levene's Test for Equality of Variances } \\
\cline { 3 - 4 } & F & Sig. \\
\hline Nilai & $\begin{array}{l}\text { Equal variances assumed } \\
\text { Equal variances not } \\
\text { assumed }\end{array}$ & .320 & .572 \\
\hline
\end{tabular}

Tabel 3 menunjukkan bahwa nilai Sig. $(0.572)>\alpha(0.05)$. Dengan demikian, data memiliki varian yang sama.

Tabel 04: hasil uji Independent sample t test

\begin{tabular}{|c|c|c|c|c|c|c|c|}
\hline \multicolumn{8}{|c|}{ t-test for Equality of Means } \\
\hline \multirow[b]{2}{*}{$\mathrm{T}$} & \multirow[b]{2}{*}{ df } & \multirow{2}{*}{$\begin{array}{l}\text { Sig. } \\
\text { tailed) }\end{array}$} & \multirow{2}{*}{ Mean Difference } & \multirow{2}{*}{$\begin{array}{l}\text { Std. } \\
\text { Difference }\end{array}$} & \multirow{2}{*}{ Error } & \multicolumn{2}{|c|}{$\begin{array}{l}95 \% \text { Confidence Interval o } \\
\text { the Difference }\end{array}$} \\
\hline & & & & & & Lower & Upper \\
\hline-2.353 & 165 & .020 & -4.21306 & 1.79078 & & -7.74886 & -.67726 \\
\hline-2.279 & 115.784 & .025 & -4.21306 & 1.84881 & & -7.87492 & -.55119 \\
\hline
\end{tabular}

Nilai Sig. (2-tailed) $<\alpha(0.05)$ menunjukkan bahwa Ho ditolak Ha diterima. Dengan demikian, ada perbedaan hasil belajar AKM 1 antara mahasiswa dengan gaya kognitif field independent dengan field dependent.

Perbedaan hasil belajar pada gaya kognitif yang berbeda ini bisa disebabkan karena karakter dari materi AKM 1 yang hampir sebagian besar analisis, dilihat dari sudut karakteristik mata kuliah AKM 1 antara lain (1) membutuhkan mahasiswa yang memiliki dan bisa mengembangkan keterampilan problem solving (Jones dan Wright, 2011), (2) kandungan materinya membutuhkan tingkat kognitif yang lebih tinggi (3) membutuhkan kemampuan yang lebih besar dalam memproses pengetahuan sebelumnya (Carrington, 2012; Cambel dkk, 2010) dimana mahasiswa yang memiliki gaya kognitif field independent lebih mudah memahami materi karena memiliki kelebihan dalam bidang analisis daripada gaya kognitif field dependent. Hal ini sesuai dengan pendapat Witkin (1971) yang menyatakan bahwa kemampuan dalam menganalisis merupakan kecenderungan mahasiswa dalam dimensi field independent. Hal ini juga senada dengan penelitian yang pernah dilakukan oleh Davis (1991); 
Tinajero dan Páramo (1997) yang menunjukkan bahwa ada sebuah pola yang konsisten dimana peserta didik dengan dimensi field independent tampil secara signifikan lebih baik daripada siswa dengan dimensi field dependent hampir dalam seluruh area kurikulum. Hasil yang sama juga terjadi terhadap mahasiswa akuntansi di Brazil (Oliveira dan Souza, 2009) dalam (Tinajero, Lemos, Araújo, Ferraces, Páramo, 2012).

Dari paparan di atas, dapat ditarik sebuah kesimpulan bahwa mahasiswa akan lebih memiliki kemungkinan berhasil dalam menempuh AKM 1 jika tergolong dalam kelompok field independent daripada field dependent karena mempunyai kemampuan problem solving dan analisis yang lebih baik. Perbedaan hasil belajar antara mahasiswa yang memiliki gaya kognitif FI dengan FD memberikan sinyal bahwa diperlukan strategi pembelajaran yang lebih bervariasi mengingat terjadi perbedaan karakteristik yang sangat mencolok diantara kedua dimensi gaya kognitif tersebut. Dengan demikian, untuk membantu peserta didik yang mengalami kesulitan dalam menganalisis dalam hal ini anak yang termasuk dimensi FD dimana mereka lebih memfokuskan perhatian pada lingkungan sosial dengan kelebihan mereka dalam interpersonal skill (Witkin, 1971), maka strategi pembelajaran kooperatif mungkin lebih efektif dibandingkan pembelajaran secara mandiri dalam menyelesaikan tugas-tugas AKM 1. Oleh karena itu, peneliti selanjutnya dianjurkan untuk mengujicobakan metode pembelajaran kooperatif, misalkan dengan metode tutor sebaya dalam rangka meningkatkan hasil belajar peserta didik secara keseluruhan.

Pengetahuan atas karakteristik dimensi field dependent dan field independent menjadi akan bermanfaat jika diterapkan dalam permasalahan yang berhubungan dengan pendidikan. Dengan mengetahui gambaran tentang bagaimana siswa belajar, bagaimana guru mengajar, bagaimana siswa dan guru berinteraksi, serta bagaimana siswa membuat keputusan memilih pekerjaan diharapkan bisa memberikan kemudahan mencari solusi permasalahan yang mungkin muncul dalam pendidikan (Witkin, 1973).

\section{DAFTAR RUJUKAN}

Allinson, C. W. dan Hayes, J. (1996). 'The Cognitive Style Index: a measure of intuition analysis for organizational research.' Journal of Management Studies, 33 (1), 119-135.

Campbell, A., Choo, F., Linsay, D.H., Tan, K.B. 2010. Trend in Accounting Student Characteristics: Results from 2005-2010 Archival Transcript Data. 
Online,(http://www.aabri.com/OC2012Manuscripts/OC12013.pdf), diakses 20 Oktober 2012.

Carrington, L.G. 2012. Ready For Intermediate Accounting? Factors Affecting Student Preparation. Makalah disajikan dalam Konferensi Akademik Internasional. Orlando, Florida, USA.

Davis, J. 1991. Educational Implications of Field Dependence, in S. Wagner \& J. Demick (Eds.) Field Dependence-Independence: Cognitive Styles across the Life Span (Hillsdale, NJ; Erlbaum) 149-176.

Eikner, A.E. dan Montondon, L. 2001. Evidence on Factors Associated with Success in Intermediate Accounting I.Accounting Educators' Journal, (Online), Volume XIII 1-17, (http://www.aejournal.com/ojs/index.php/aej/article/viewFile/24/24), diakses 26 Oktober 2012.

Gordon, H.R., dan Wyant, L. J. 1994. Cognitive Style of Selected International and Domestic Graduate Students at Marshall University. (Online), (http://eric.ed.gov/ERIC

Docs/data/ericdocs2sq1/content_storage_01/000019b/80/13/e8/ic.pdf, diakses 22 Mei 2009.

Hicks, D.W., dan Richardson, F. (1984) Predicting early success in intermediate accounting: The influence of entry exam and GPA. Issues in Accounting Education, 61-76.

Hicks, E., R. Bagg, W. Doyle, dan J. Young. 2007. Public Accountants' Field Dependence: Canadian Evidence. Perceptual and Motor Skills. (Vol. 105) 11 :27-35.

Jones, S.H., dan Wright, M. 2011.Effect Of Cognitive Style On Performance In Introductory Financial Accounting And The Decision To Major In Accounting. Global Perspectives On Accounting Education, (Online), Volume 8, 2011, 7-26, http://web.bryant.edu/ gpae/Vol8/Cognitive\%20Style\%20on\%20Performance.p df. Diakses 10 November 2012.

Jones, S.H., dan Wright, M. 2012. Does Cognitive Style Affect Performance On Accounting Examination Questions?. Global Perspectives On Accounting Education, (Online), Volume 9, 2012, 31-52, http://web.bryant.edu/ gpae/Vo19/Cognitive\%20Style\%20Affect\%20Performan ce\%20on\%20Exam\%20Questions.pdf. Diakses 10 November 2012.

Tegeh, I. M. 2009. Perbandingan Prestasi Belajar Mahasiswa yang Diajar dengan Menggunakan Problem Based Learning dan Ekspository yang Memiliki Gaya Kognitif Berbeda. Disertasi Tidak Diterbitkan. Malang: Program Pascasarjana UM 
Tinajero, C., dan Páramo, M. F. (1997). Field dependence-independence and academic achievement: A reexamination of their relationship. British Journal of EducationalPsychology, 67, 199-212

Tinajero, C., Lemos, S. M., Araújo, M., Ferraces, M. J., Páramo, M. F. 2012. Cognitive Style and Learning Strategies as Factors which Affect Academic Achievement of Brazilian University Students. Jurnal Psicologia: Reflexão e Crítica, 25 (1): 105113

Turner, J., S.A. Holmes, dan C.E. Wiggins. (1997). Factors associated with grades in intermediate accounting. Journal of Accounting Education, 15(2), 269-288.

Waples, E. dan Darayseh, M. 2005. Determinants Of Students' Performance In Intermediate Accounting.Journal of College Teaching \& Learning, (Online), Volume 2 No 12, (http://www.journals.cluteonline.com/index.php/TLC/article/download/1897/18 76). Diakses 10 Sepetember 2012.

Witkin, H.A. 1971. The Role of Cognitive Style in Academic Performance and in Teacher-Student Relations. Education Resources Information Center: Paper presented at a Symposium Sponsored by the Graduate Record Examination Board, Montreal, Canada, November 8-10, 1972.

Witkin, H. A., dan D.R. Goodenough. 1977. Field Dependence and Interpersonal Behavior. Psychological Bulletin (Vol. 84) 661-689. 